\title{
ANTIDIARRHOEAL ACTIVITY OF AN ETHANOL EXTRACT OF THE STEM BARK OF PILIOSTIGMA RETICULATUM (CAESALPINIACEAE) IN RATS
}

\author{
K. Dosso", B.B. N'guessan ${ }^{\# *}$, A.P. Bidie ${ }^{\S}$, B.N. Gnangoran", S. Méité ${ }^{\S}$, D. N'guessan ${ }^{\S}$, A.P. Yapo ${ }^{\#}$, \\ E.E. Ehilé
}

${ }^{\#}$ Laboratory of Physiology, Pharmacology and Phytotherapy, UFR SN, University of Abobo- Adjamé, 02 BP 801 Abidjan 02, Côte d'Ivoire. ${ }^{\S}$ Laboratory of Biochemical-

Pharmacodynamics, UFR Biosciences, University of Cocody, 22 BP 582 Abidjan 22, Côte d'Ivoire.

*E-mail: benoitnguessan@yahoo.com

\begin{abstract}
Piliostigma reticulatum (Caesalpiniaceae) is used in Africa as a traditional medicine for the treatment of many diseases, such as malaria, tuberculosis and diarrhoea. We investigated the antidiarrhoeal properties of a crude ethanol extract from the stem bark of Piliostigma reticulatum (EEPR) in Wistar albino rats to substantiate its traditional use and to determine its phytochemical constituents. The antidiarrhoeal activity of the plant extract was evaluated in a castor oil-induced diarrhoea model in rats and compared with loperamide. The effect of the extract on gastrointestinal motility was also determined by the oral administration of charcoal meal and castor oil-induced intestinal fluid accumulation (enteropooling). EEPR showed remarkable dose-dependent antidiarrhoeal activity evidenced by a reduction of defecation frequency and change in consistency. Extracts at 250,500 and $1000 \mathrm{mg} / \mathrm{kg}$ body weight significantly reduced diarrhoeal faeces. EEPR also significantly inhibited gastrointestinal motility and castor oil-induced enteropooling at 500 and $1000 \mathrm{mg} / \mathrm{kg}$, similar to the inhibition obtained in control rats treated by atropine. Phytochemical screening revealed the presence of tannins, flavonoids, polyphenols and reducing sugars in the stem bark of $P$. reticulatum. No mortality or visible signs of general weakness were observed in the rats following administration of the crude extract in doses up to $6000 \mathrm{mg} / \mathrm{kg}$ body weight in an acute toxicity study. Our results show that the stem bark of $P$. reticulatum possesses antidiarrhoeal activity and strongly suggest that its use in traditional medicine practice could be justified.
\end{abstract}

Key words: Antidiarrhoeal activity; Castor oil; Diarrhoea; Piliostigma reticulatum

\author{
Abbreviations: \\ cAMP: cyclic adenosine monophosphate \\ EEPR: ethanol extract of stem bark of Piliostigma reticulatum \\ NaCl: sodium chloride \\ WHO: World Health Organisation
}

\section{Introduction}

Diarrhoea is one of the leading causes of mortality in developing countries accounting for more than 5-8 million deaths each year in infants and small children under 5 years old (Faud et al., 1998; Mohd et al., 2004; Mujumdar et al., 2005). Most of these deaths occur in Africa (Abdullahi et al., 2001). In Côte d'Ivoire, the prevalence of diarrhoea in the population is $26.19 \%$, and in Abidjan, the country's main city, it is evaluated to be $27.9 \%$ for diarrhoeas provoked by rotavirus in infants of 0-5 years old (Akoua-Koffi et al., 1993; 2007).

The disease is characterised by a discharge of semi-solid or watery faecal matter from the bowels three or more times per day (Hirchhorn, 1980; Snyder and Merson, 1982). It involves an increase in the fluidity, volume and frequency of bowel movements, abdominal pain accompanied by increased secretion and decreased absorption of fluid and thus the loss of water and electrolytes (Fontaine, 1988; Field et al., 1989; Longe and Dipiro, 1992).

In general, the treatment of diarrhoea is aimed at reducing the discomfort and inconvenience of frequent bowel mobility (Brunton, 1996; Suleiman et al., 2008) and the frequency of faeces (Guerrant et al., 2001). In sub-Saharan Africa, up to $90 \%$ of the population depends on medicinal plants for primary health care (Hostettmann et al., 2000) and their use has been recommended by the WHO for diarrhoea control and patient management (Snyder and Merson, 1982). Therefore, medicinal plants represent a promising source for the discovery of new antidiarrhoeal agents (Maikere-Faniyo et al., 1989). Some African medicinal plants in particular have been reported for their efficiency in the treatment of diarrhoea (Abdullahi et al., 2001; Aniagu et al., 2005; Suleiman et al., 2008). Among them, Alchornea cordifolia, Euphorbia hirta, Adansonia digitata and Morinda morindoides have been studied for their antidiarrhoeal properties (Gabriel et al., 2004; Mueller and Mechler, 2005; Méité et al., 2009).

Piliostigma reticulatum is found in tropical forests of West African countries such as Côte d'Ivoire, Mali and Burkina Faso and is traditionally used against many disorders, such as ulcers (Salawu et al., 2009), boils, wounds, syphilitic cancer (Arbonier, 2002; Aderogba et al., 2003) and diarrhoea (Arbonier 2002; Yelemou et al., 2007). To the best of our knowledge, the antidiarrhoeal properties of the stem bark of this plant have not been investigated. However, chemical compounds isolated from $P$. reticulatum, such as flavonols (6-C-methylquercetin-3-methyl ether-5; 6,8-di-Cmethylkaempferol-3-methyl ether-6 and 6-C-methylquercetin-3,3',7-trimethyl ether-7) and oxychromonol (6-C-methyl-2-p- 
hydroxyphenyloxychromonol, or piliostigmol), have been shown to exhibit antimicrobial activities against bacteria (Escherichia coli and Bacillus subtilis) and fungi (Aspergillus niger and Candida albicans) that cause infectious diarrhoeas (Babajide et al., 2008). Furthermore, antidiarrhoeal activity of the roots of $P$. reticulatum has been reported by Salawu et al (2007).

The present study was conducted to investigate the potential in vivo antidiarrhoeal activity of an ethanol extract from the stem bark of Piliostigma reticulatum (EEPR) in a castor oil-induced model of diarrhoea in rats as well as to screen its phytochemical constituents.

\section{Materials and methods Plant materials}

Stem bark from Piliostigma reticulatum (DC.) Horscht (Caesalpiniaceae) was collected in Abidjan (southern region of Côte d'Ivoire) in October 2007. The plant was identified and authenticated by Professor Ake-Assi Laurent. A voucher specimen $\left(\mathrm{N}^{\circ} 18033\right)$ of the plant was deposited in the herbarium of the National Centre of Floristic of University of CocodyAbidjan.

\section{Ethanol extract preparation}

Stem bark samples of Piliostigma reticulatum were cleaned, washed with distilled water, cut into smaller pieces and kept at room temperature for two weeks. They were then ground into a fine powder. The powder $(100 \mathrm{~g})$ was extracted with two litres of a solution of ethanol (96\%)/water (80:20) for 24 hours under constant stirring; this operation was repeated twice. The extract was filtered twice through cotton wool, then through Whatman filter paper $\left(\mathrm{N}^{\circ} 1\right)$. The filtrate was evaporated to dryness using a rotavapor apparatus (Buchi R110/NKE6540/2) at $45^{\circ} \mathrm{C}$ and dried under reduced pressure. The percentage yield was found to be $13.6 \%$.

\section{Animals}

Healthy young adult albino Wistar rats (weighing 150-200 g) of both sexes that were provided by UFR Biosciences (University of Cocody-Abidjan, Côte d'Ivoire) were housed in standard metal cages. They were kept under standard laboratory temperature conditions one week before the experiments for acclimation. The animals were fed with a diet of commercial pellets (Ivograin $^{\circledR}$, Abidjan, Côte d'Ivoire) and were given water ad libitum. They were deprived of food for at least $18 \mathrm{~h}$ prior to experiments but allowed free access to drinking water. The equipment usage and handling and sacrificing of the animals were in accordance with the European Council legislation 87/609/EEC for the protection of experimental animals (Mitjans, 2008).

\section{Drugs and chemicals}

Atropine sulphate and loperamide (Sigma Chemical Co., St. Louis, MO, USA), castor oil (Qualikems Fine Chemicals Pyt. Ltd., New Delhi, India), normal saline ( $\mathrm{NaCl} 0.9 \%$ ) and charcoal meal (10\% active charcoal in $100 \mathrm{ml}$ of $5 \%$ aqueous gum acacia) were used.

\section{Castor oil-induced diarrhoea in rats}

Thirty rats were fasted for $18 \mathrm{~h}$ and divided into five groups of six animals. The ethanol extract of $P$. reticulatum at doses of 250,500 and $1000 \mathrm{mg} / \mathrm{kg}$ body weight was administered orally to groups 1, 2 and 3, respectively. The fourth group received normal saline $(\mathrm{NaCl} 0.9 \%)$ and served as the negative control, while the fifth group received the standard drug, loperamide $(5 \mathrm{mg} / \mathrm{kg}$ body weight). One hour after drug pre-treatment, all of the animals received $2 \mathrm{ml}$ of castor oil orally. The animals were kept in separate metabolic cages with a transparent plastic container beneath the cage to collect faeces (Awouters et al., 1978). The severity and consistency of diarrhoea was observed at 1, 2, 3, 4, 5 and 6 hours after castor oil administration. The total number of faeces (both diarrhoeal and non-diarrhoeal) expelled in the groups treated with the plant extract was compared with the positive control group. The total diarrhoeal faeces for the control group were considered to be $100 \%$. The results were expressed as a percentage of inhibition of diarrhoea.

Percentage of wet faeces inhibition $=\left(\mathrm{T}_{0}-\mathrm{T}_{1} / \mathrm{T}_{0}\right) * 100$

$\mathrm{T}_{0}=$ number of wet faeces in control group

$\mathrm{T}_{1}=$ number of wet faeces in test group

Severity of diarrhoea $=($ diarrhoeal faeces $/$ total faeces $) * 100$

\section{Gastrointestinal motility test}

Thirty rats were divided into five groups of six animals each and were fasted for $18 \mathrm{~h}$ with free access to water. The first group (control group) received normal saline $(\mathrm{NaCl} 0.9 \%$ ) orally, while the second, third and fourth groups were given the plant extract orally at doses of 250,500 and $1000 \mathrm{mg} / \mathrm{kg}$ body weight, respectively. The fifth group received the standard drug, atropine ( $5 \mathrm{mg} / \mathrm{kg}$ body weight). After 60 minutes, each animal was given $1 \mathrm{~mL}$ per rat of charcoal meal via the oral route. After anaesthesia with chloroform, all animals were sacrificed after $60 \mathrm{~min}$ by opening the abdomen, and the distance covered by the charcoal meal in the intestine, from the pylorus to the caecum, was measured and expressed as the percentage of distance moved (Pazhani et al., 2001). 
Percentage of transit inhibition $=\left(\mathrm{T}_{0}-\mathrm{T}_{1} / \mathrm{T}_{0}\right) \times 100$

$\mathrm{T}_{0}=$ total length of intestine

$\mathrm{T}_{1}=$ charcoal distance of test group

\section{Castor oil-induced enteropooling}

Intraluminal fluid accumulation was determined by the method of Robert et al. (1976). Thirty rats were divided into five groups. One hour before the oral administration of castor oil, group 1 received normal saline $(\mathrm{NaCl} 0.9 \%)$ orally, serving as the control. Group 2 received loperamide, the standard drug $(5 \mathrm{mg} / \mathrm{kg}$ body weight). The other three groups received the extract at doses of 250,500 and $1000 \mathrm{mg} / \mathrm{kg}$ body weight. Two hours later, the rats were sacrificed, and the small intestine from the pylorus to the caecum was isolated. The intestinal contents were recovered into a graduated tube, and their volume was measured.

\section{Acute toxicity testing}

Thirty five rats were divided in seven groups of five animals. The ethanol extract of $P$. reticulatum was administrated orally at doses of $250,500,1000,2000,4000$ and $6000 \mathrm{mg} / \mathrm{kg}$ body weight to the animal groups (one dose per group). The control group received normal saline $(\mathrm{mg} / \mathrm{kg})$. General signs of weakness and symptoms of toxicity, food and water intake and mortality were recorded for a period of 48 hours and then for a period of 14 days.

\section{Phytochemical screening}

The extract was screened for the presence of tannins, flavonoids, alkaloids, sterols, saponins, polyphenols, polyterpenes and anthraquinones. Detection of these constituents was performed according to Bekro et al. (2007).

\section{Statistical analysis}

The results were expressed as the mean \pm SEM. Data were analysed for statistical significance by one-way ANOVA followed by the Fisher-Snedecor test using the SAS statistical program (1999). At a 95\% confidence interval, $p<$ 0.05 was considered to be statistically significant.

\section{Results}

\section{Effect of ethanol extract of $P$. reticulatum on castor oil-induced diarrhoea}

In the castor oil-induced diarrhoea experiment, the extract of $P$. reticulatum produced a marked antidiarrhoeal effect in rats, as shown in Table 1. Compared to total number of diarrhoeal faeces of the control (16.17 \pm 3.37$)$, the number of diarrhoeal faeces was $10.33 \pm 2.80,8.17 \pm 1.94$ and $6.33 \pm 2.06$, respectively, for 250,500 and $1000 \mathrm{mg} / \mathrm{kg}$. At these doses, the extract significantly inhibited the number of diarrhoeal faeces (Table 1). The effect of the highest dose of the extract was similar to that of loperamide $(5.67 \pm 3.44)$. In our model, diarrhoeal faeces appeared within the first few hours in the control group, while in the treated groups, they only appeared 4 hours after diarrhoea induction (for a dose of $500 \mathrm{and} 1000 \mathrm{mg} / \mathrm{kg}$ extract), similar to the loperamide group (see Table 2 and Figure 1). The effect in the $250 \mathrm{mg} / \mathrm{kg}$ extract treated group was the same as that in the control group.

Table 1: Effects of an ethanol extract of $P$. reticulatum on castor oil-induced diarrhoea in albino rats.

\begin{tabular}{ccccc}
\hline Groups & $\begin{array}{c}\text { Number total of } \\
\text { faeces }\end{array}$ & $\begin{array}{c}\text { Number of } \\
\text { diarrhoeal faeces }\end{array}$ & Severity of diarrhoea (\%) & $\begin{array}{c}\text { Inhibition of } \\
\text { diarrhoea (\%) }\end{array}$ \\
\hline Control & $17.0 \pm 1.18$ & $16.17 \pm 3.37$ & 95.11 & - \\
Loperamide & $8.33 \pm 3.93^{*}$ & $5.67 \pm 3.44^{*}$ & 68.06 & 64.93 \\
$\begin{array}{c}\mathrm{EEPR} \\
(250 \mathrm{mg} / \mathrm{kg})\end{array}$ & $12.0 \pm 3.74$ & $10.33 \pm 2.80^{*}$ & 86.08 & 36.12 \\
$\begin{array}{c}\mathrm{EEPR} \\
(500 \mathrm{mg} / \mathrm{kg})\end{array}$ & $11.33 \pm 1.50^{*}$ & $8.17 \pm 1.94^{*}$ & 72.10 & 49.47 \\
$\mathrm{EEPR}$ & $9.67 \pm 3.07^{*}$ & $6.33 \pm 2.06^{*}$ & 65.46 & 60.85 \\
\hline
\end{tabular}

Values are the mean $\pm \operatorname{SEM}(\mathrm{n}=6) ;{ }^{*}$ Significant as compared to respective control, $\mathrm{p}<0.05$.

\section{Effect of Piliostigma reticulatum ethanol extract on intestinal transit of charcoal meal}

The ethanol extract of $P$. reticulatum significantly decreased the propulsion of charcoal meal in rat gastrointestinal tracts by $42.08 \pm 9.20$ and $38.18 \pm 10.21 \%$, respectively, at 500 and $1000 \mathrm{mg} / \mathrm{kg}$ compared to the negative control $(88.07 \pm$ $15.78 \%$ ). A similar reduction in the gastrointestinal transit of charcoal meal in rats was achieved with atropine sulphate $(45.61 \pm 27.75 \%)$. Results are shown in Table 3 and Figure 2. 
Table 2: Effects of an ethanol extract of $P$. reticulatum on diarrhoeal faeces per total faeces in albino rats over the course of 6 hours.

\begin{tabular}{|c|c|c|c|c|c|c|}
\hline \multirow[t]{2}{*}{ Groups } & \multicolumn{4}{|c|}{ Diarrhoeal faeces / Total faeces } & \multirow[b]{2}{*}{ T5 } & \multirow[b]{2}{*}{ T6 } \\
\hline & T1 & $\mathbf{T 2}$ & T3 & T4 & & \\
\hline Control & $\begin{array}{c}4.5 \pm 2.2 \\
/ 4.8 \pm 2.0\end{array}$ & $\begin{array}{l}5.8 \pm 2.5 \\
/ 6.0 \pm 1.6\end{array}$ & $\begin{array}{c}8.3 \pm 2.3^{\#} \\
/ 8.3 \pm 2.3^{\#}\end{array}$ & $\begin{array}{l}12.7 \pm 1.7^{\# \# \# \S \xi \xi \mu} \\
/ 13.0 \pm 1.1^{\# \# \# \xi \xi \xi \mu}\end{array}$ & $\begin{array}{l}14.0 \pm 1.1^{\# \# \xi \xi \xi \mu \mu} \\
/ 14.7 \pm 0.8^{\# \# \xi \xi \mu \mu}\end{array}$ & $\begin{array}{c}16.2 \pm 0.6^{\# \# \xi \xi \xi \mu \pi} / 16.5 \\
\pm 0.6^{\# \# \xi \mu \mu \pi}\end{array}$ \\
\hline Loperamide & $\begin{array}{l}0 \pm 0^{*} \\
/ 0 \pm 0^{* *}\end{array}$ & $\begin{array}{c}0 \pm 0^{* *} \\
/ 1.0 \pm 0.5^{* *}\end{array}$ & $\begin{array}{l}0.5 \pm 0.05^{* * *} \\
/ 1.7 \pm 0.6^{* * *+}\end{array}$ & $\begin{array}{l}1.8 \pm 0.7^{* * * \dot{\gamma}} \\
/ 3.7 \pm 0.5^{* * * \dagger}\end{array}$ & $\begin{array}{l}4.0 \pm 1.2^{* * * \dot{ }} \\
/ 5.5 \pm 0.2^{* * * \dagger}\end{array}$ & $\begin{aligned} 5.7 & \pm 1.4^{* * * \dagger \dagger} \\
/ 7.3 & \pm 0.5^{* * * \dagger \dagger}\end{aligned}$ \\
\hline EEPR 250 & $\begin{array}{l}0.2 \pm 0.07^{*} \\
/ 1.3 \pm 0.4^{*}\end{array}$ & $\begin{array}{l}0.2 \pm 0.07^{* *} \\
/ 1.5 \pm 0.5^{*}\end{array}$ & $\begin{array}{l}3.0 \pm 0.7^{* *} \\
/ 5.0 \pm 0.3^{*}\end{array}$ & $\begin{array}{l}5.3 \pm 1.4^{* * *} \\
/ 6.8 \pm 0.6^{* * *}\end{array}$ & $\begin{array}{l}8.3 \pm 1.0^{* * £ £ \$ \$} \\
/ 10.0 \pm 0.2^{* £ £ \$}\end{array}$ & $\begin{array}{l}10.3 \pm 1.4^{* * \$} \\
/ 13.0 \pm 0.2^{* * \$}\end{array}$ \\
\hline EEPR 500 & $\begin{array}{c}0 \pm 0^{*} \\
/ 1.8 \pm 0.3^{*}\end{array}$ & $\begin{array}{c}0 \pm 0^{* *} \\
/ 2.8 \pm 0.3^{*}\end{array}$ & $\begin{array}{c}0 \pm 0^{* *} \\
/ 4.0 \pm 0.2^{*}\end{array}$ & $\begin{array}{l}2.5 \pm 0.8^{* * *} \\
/ 4.2 \pm 0.3^{* * *}\end{array}$ & $\begin{array}{l}3.5 \pm 1.7^{* *} \\
/ 5.7 \pm 0.6^{* * * f}\end{array}$ & $\begin{array}{c}8.2 \pm 0.9^{* *} \\
/ 9.7 \pm 0.4^{* * *} £\end{array}$ \\
\hline EEPR 1000 & $\begin{array}{c}0 \pm 0^{*} \\
/ 2.7 \pm 0.2^{*}\end{array}$ & $\begin{array}{c}0 \pm 0^{* *} \\
/ 3.1 \pm 0.4^{*}\end{array}$ & $\begin{array}{l}0 \pm 0^{* * *} \\
/ 3.5 \pm 0.4^{* * *}\end{array}$ & $\begin{array}{l}2.3 \pm 1.2^{* * * \$} \\
/ 4.5 \pm 0.4^{* * * \$}\end{array}$ & $\begin{array}{c}2.7 \pm 1.3^{* * *} \\
/ 5.7 \pm 0.2^{* * * £ \$}\end{array}$ & $\begin{array}{c}6.3 \pm 0.8^{* * * \$} \\
/ 9.0 \pm 0.5^{* * * \$}\end{array}$ \\
\hline
\end{tabular}

Values are expressed as mean \pm SEM $(n=6)$. Statistical comparisons: ${ }^{\#} \mathrm{~T} 1$ vs. $\left(\mathrm{T} 2, \mathrm{~T} 3, \mathrm{~T} 4, \mathrm{~T} 5\right.$ or T6); ${ }^{\S} \mathrm{T} 2$ vs. $(\mathrm{T} 3, \mathrm{~T} 4, \mathrm{~T} 5$ or T6); ${ }^{\mu} \mathrm{T} 3$ vs. (T4, T5, or T6); ${ }^{\pi} \mathrm{T} 4$ vs. (T5 or T6); ${ }^{\alpha} \mathrm{T} 5$ vs. T6;

${ }^{*}$ Control vs. (Loperamide, EEPR250, EEPR500 or EEPR1000); ${ }^{\dagger}$ Loperamide vs. (EEPR250, EEPR500 or EEPR1000); ${ }^{£}$ EEPR250 vs. EEPR500; ${ }^{\$}$ EEPR250 vs. EEPR1000.

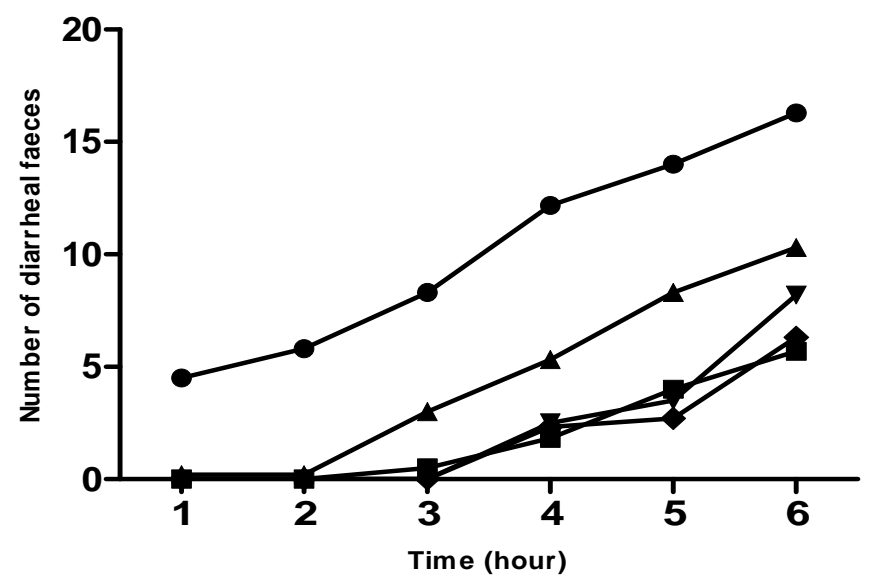

Normal saline $\neg$ Loperamide $\longrightarrow$ EEPR $250 \rightarrow$ EEPR $500-$ EEPR 1000

Figure 1. Effects of ethanol extract of P. reticulatum on castor oil-induced diarrhoea in albino rats over 6 hours.

Effect of Piliostigma reticulatum ethanol extract on castor oil-induced enteropooling

The ethanol extract significantly $(\mathrm{p}<0.05)$ inhibited castor oil-induced enteropooling by 19.80 and $23.05 \%$, respectively, at 500 and $1000 \mathrm{mg} / \mathrm{kg}$ compared to the control. Loperamide reduced the volume of the intestine contents significantly by $34.74 \%(\mathrm{p}<0.05)$ (Table 4$)$.

Table 3: Effects of an ethanol extract of $P$. reticulatum on the intestinal transit of charcoal meal in rats

\begin{tabular}{|c|c|c|c|}
\hline Groups & $\begin{array}{l}\text { Total distance of } \\
\text { intestine }(\mathrm{cm})\end{array}$ & $\begin{array}{c}\text { Distance travelled by } \\
\text { charcoal (\%) }\end{array}$ & Inhibition of mobility (\%) \\
\hline Normal saline $(5 \mathrm{mg} / \mathrm{kg})$ & $112.50 \pm 7.09$ & $88.07 \pm 15.78$ & 21.71 \\
\hline Atropine $(5 \mathrm{mg} / \mathrm{kg})$ & $111.65 \pm 5.97$ & $45.61 \pm 27.75^{*}$ & 59.15 \\
\hline $\operatorname{EEPR}(250 \mathrm{mg} / \mathrm{kg})$ & $108 \pm 9.79$ & $66.11 \pm 9.26$ & 38.78 \\
\hline EEPR (500 mg/kg) & $107.87 \pm 7.15$ & $42.08 \pm 9.20^{*}$ & 60.99 \\
\hline EEPR $(1000 \mathrm{mg} / \mathrm{kg})$ & $106.51 \pm 6.62$ & $38.18 \pm 10.21^{*}$ & 64.15 \\
\hline
\end{tabular}

Values are mean \pm SEM $(n=6) ;$ " Significant as compared to control, $p<0.05$ 
Table 4: Effects of an ethanol extract of $P$. reticulatum on castor oil-induced enteropooling in rats

\begin{tabular}{lcc}
\hline \multicolumn{1}{c}{ Groups } & $\begin{array}{c}\text { Volume of intestinal } \\
\text { fluid (ml) }\end{array}$ & $\begin{array}{c}\text { Inhibition of intestinal fluid } \\
(\mathbf{\%})\end{array}$ \\
\hline Normal saline $(5 \mathrm{mg} / \mathrm{kg})$ & $3.08 \pm 0.14$ & - \\
Loperamide $(5 \mathrm{mg} / \mathrm{kg})$ & $2.01 \pm 0.14$ & 34.74 \\
EEPR $(250 \mathrm{mg} / \mathrm{kg})$ & $3.05 \pm 0.16$ & 0.97 \\
EEPR $(500 \mathrm{mg} / \mathrm{kg})$ & $2.47 \pm 0.05$ & 19.80 \\
EEPR $(1000 \mathrm{mg} / \mathrm{kg})$ & $2.37 \pm 0.03$ & 23,05 \\
\hline
\end{tabular}

Values are mean \pm SEM $(n=6) ;{ }^{*}$ Significant as compared to control, $p<0.05$

Table 5: Phytochemical screening of an ethanol extract of stem bark from P. reticulatum

\begin{tabular}{cc}
\hline chemical constituents & Piliostigma reticulatum \\
\hline Polyphenols & + \\
Sterols and polyterpernes & - \\
Flavonoids & ++ \\
Saponins & - \\
Tannins & ++ \\
Alkaloids & - \\
Anthraquinones & - \\
Reducing sugars & + \\
Coumarins & - \\
\hline
\end{tabular}

$(-)$ absence, $(+)$ presence, $(++)$ major chemical constituents.

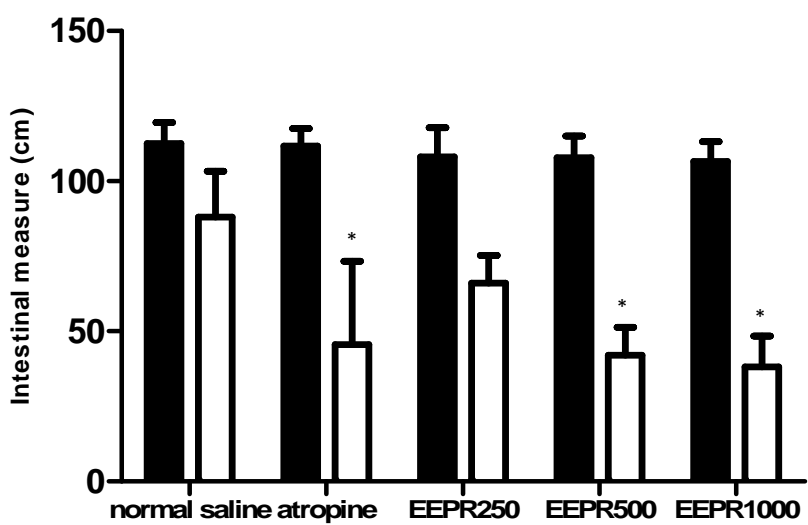

Animal groups

Figure 2: Effects of ethanol extract on the gastrointestinal transit of charcoal meal in rats, ${ }^{*} \mathrm{p}<0.05$ vs. control.

\section{Acute toxicity study}

The behaviour and the faeces of the animals were normal. We did not observe others signs of weakness or mortality in rats receiving up to a dose $6000 \mathrm{mg} / \mathrm{kg}$ body weight by oral administration of the ethanol extract $P$. reticulatum. These findings suggest that the extract of the stem bark of $P$. reticulatum is safe or non-toxic to rats.

\section{Phytochemical tests}

Phytochemical screening tests for various constituents revealed the presence of major components such as tannins and flavonoids. Polyphenols and reducing sugars were present, and anthraquinones, alkaloids, coumarins, polyterpenes and sterols were absent (Table 5).

\section{Discussion}

The present study sought to assess the antidiarrhoeal activity of Piliostigma reticulatum. This plant was 
ethnobotanically selected during a survey conducted in 2005 in the city of Abidjan (Côte d'Ivoire). The results of the survey (data not shown) have allowed us to collect 17 antidiarrhoeal plant species, among which Piliostigma reticulatum was strongly advised. Moreover, the stem bark of this plant has never been studied for its antidiarrhoeal properties to our knowledge.

We observed that the extract did not provoke any visible toxic manifestations (respiratory distress, uncoordinated muscle movements, etc.) or mortality in animals. Our study showed that an ethanol extract of the stem bark of $P$. reticulatum significantly inhibited castor oil-induced diarrhoea in rats, as shown by the significant reduction of the number of diarrhoeal and total faeces. In our study, extract from stem bark inhibited diarrhea by $36.12,49.47$ and $60.85 \%$ and gastrointestinal tract by $38.78,60.99$ and $64.15 \%$, respectively, at 250,500 and $1000 \mathrm{mg} / \mathrm{kg}$. The study of Salawu et al (2007) reported an inhibition of diarrhea by 53.5 and $72.1 \%$ and a reduction of gastrointestinal tract by 9.38 and $21.74 \%$, respectively, at 100 and $200 \mathrm{mg} / \mathrm{kg}$. These different results suggest that the roots of $P$. reticulatum may contain high concentration of antidiarrheal components compared to the stem bark. Moreover, our results directly demonstrate an inhibition of castor oilinduced enteropooling as shown by the decrease in the volume of intestinal content. Therefore, we can assume that the antidiarrhoeal action of the ethanol extract of $P$. reticulatum could be mediated in part by a mechanism involving a decrease of gastrointestinal secretion and motility. Indeed, it is well established that castor oil produces diarrhoea by the release of ricinoleic acid, which results in irritation and inflammation of the intestinal mucosa, leading to a release of prostaglandins; these stimulate gastrointestinal motility and the secretion of water and electrolytes (Pierce et al., 1971; Gaginella and Bass, 1978 ; Galvez et al., 1993; Capasso et al., 1994). Water and electrolyte secretions were not investigated in the present study, and further investigations should be undertaken to elucidate the effect of the ethanol extract of $P$. reticulatum on this mechanism. However, the significant reduction of the number of diarrhoeal faeces, the prolonged time for the appearance of wet stools and the decrease in the volume of intestinal content by the plant extract could reinforce this hypothesis of a reduction in water and electrolytes secretion. The similarity of the results obtained by the extract and the standard drug loperamide on the reduction of gastrointestinal motility and diarrhoeal faeces could also confirm our assumption. Indeed, it is well documented that loperamide antagonises diarrhoea induced by castor oil (Niemegeers et al., 1974), prostaglandins (Karim and Adaikan, 1977) or cholera toxin (Farack et al., 1981). These actions are due to its anti-motility and antisecretory properties (Couper, 1987).

The phytochemical screening of the stem bark of $P$. reticulatum showed that tannins and flavonoids are the major components, whereas polyphenols and reducing sugars were minor components. The result also showed the absence of sterols, polyterpenes, saponins, alkaloids, anthraquinones, and coumarins. These observed components could be responsible for the antidiarrhoeal activity of the ethanol extract of stem bark from P. reticulatum. Our results are in agreement with many studies in the literature. It was reported that flavonoids, tannins (Murugessan et al., 2000; Abdullaih et al., 2001; Havagiray et al., 2004; Attia et al., 2005), polyphenols, polyterpenes, reducing sugars and saponins (Gabriel et al., 2004; Havagiray et al., 2004; Ojewole et al., 2009; Méité et al., 2009) were responsible for the antidiarrhoeal properties of certain plants such as Alchornea cordifolia, Calotropis gigantea and Morinda morindoides.

The antidiarrhoeal activity of flavonoids has been demonstrated and attributed to their ability to inhibit intestinal motility and hydro-electrolytic secretions (Rao et al., 1997; Di Carlo et al., 2005). In vitro and in vivo experiments on animals have shown that flavonoids are able to inhibit the intestinal secretory response induced by prostaglandin $\mathrm{E}_{2}$ (Sanchez et al., 1997) and contractions induced by spasmogens (Macauder, 1986; Capasso et al., 1988). Flavonoids are also known to inhibit the release of autocoids and prostaglandins, thereby inhibiting the motility and secretion induced by castor oil (Vimala et al., 1997; Nikiema et al., 2001). In addition, flavonoids present antioxidant properties that are presumed to be responsible for the inhibitory effects exerted upon several enzymes, including those involved in arachidonic acid metabolism (Mora et al., 1990; Su et al., 2000). Tannins form protein tannate that reduces intestinal secretions (Tripathi, 1994; Atta and Mouneir, 2005), and Oi et al. (2000) reported that galloyl-tannins (RG-tannin) isolated from rhubarb were effective in inhibiting cholera toxin activities, including fluid accumulation in ileal loops isolated from rabbits and mice. Polyphenols, by their antidiarrhoeal property, interact with and inhibit cytochrome P450 systems. This can impact the pharmacokinetics of any co-administered drugs metabolised by these systems (Zhou et al., 2000). The antidiarrhoeal activity of the ethanol extract of the stem bark of $P$. reticulatum could therefore be due to the presence of tannins, flavonoids and polyphenols.

\section{Conclusion}

Our results demonstrate that the stem bark of $P$. reticulatum contains bioactive natural substances with antidiarrhoeal properties. These attributes may provide a rationale for the use of $P$. reticulatum in diarrhoea management by traditional healers. Moreover, the use of aerial parts of the plant could represent an alternative to the utilisation of its roots, therefore limiting the biodiversity degradation.

\section{Acknowledgements}

This project was supported in part by the Non-Governmental Organisation for the Promotion of Scientific Research in African Traditional Medicine (NGO "PRORESMAT"). The authors wish to thank Professor Ake-Assi Laurent of the National Centre of Floristic, University of Cocody-Abidjan for botanical identification of the plant, Doctor Boua Boua Benson of the University of Abobo-Adjamé for his help in Phytochemical screenings and Doctor Kouassi Ignace of the University of Abobo-Adjamé for statistical analysis. 


\section{References}

1. Abdullahi, AL., Agho, MO., Amo, SS., Gamaniel, KS., Wambebe, C (2001). Antidiarrhoeal activity of the aqueous extract of Terminalia avicennoides roots. Phytother Res., 15: 431-434.

2. Aderogba, MA., Okoh, EK., Ogundaini, AO., Abegaz, BM (2003). C-methylquercetin-3,3',4'-trimethyl ether from the leaves extract of Piliostigma reticulatum. Nigerian J Nat prod Med., 7: 37-8.

3. Akoua-Koffi, G., Faye-Hette, H., Kouakou, K., Timite-Konan, M., Coulibaly, K. et Dosso,M (1993). Intérêt d'utilisation d'un test au latex (rotalex) pour le dépistage de rotavirus dans les selles diarrhéiques à Abidjan. Médecine d'Afrique Noire. ISSN 0465-4668 CODEN MAFNAS Vol. 40 n¹0: 599-602.

4. Akoua-Koffi, G., V, Akran., I, Peenze., V, Adjogoua., MC, De Beer., AD, Steele., M, Dosso and A, Ehouman (2007). Aspects épidémiologiques et virologiques des diarrhées dues aux rotavirus à Abidjan, Côte d'Ivoire (1997-2000). Bull soc pathol Exot., 4: 246-249.

5. Aniagu, SO., Blinda, LG., Nwinyi, F.C (2005). Antidiarrhoeal and ulcer-protective effects of the aqueous root extract oh Guiera senegalensis in rodents. J Ethnopharmacol., 97 : 549-554.

6. Arbonier, M (2002). Arbres, Arbustes et Lianes des zones sèches de l'Afrique de l'Ouest, Edition 2, CIRAD, MNHN, 574p.

7. Atta, A., Mouneir, S (2005). Evaluation of some medicinal plant extracts for antidiarrhoeal activity. Phytother Res., 19: 481-485.

8. Awouters, F., Niemegeers, CJE., Lenaerts, FM., Janseen, PAJ (1978). Delay of castor oil inrats; a new way to evaluate inhibitors of prostaglandin biosynyhesis. J Pharmacol., 30: 41-45.

9. Babajide, OJ., Babajide, OO., Daramola, AO., Mabusela, WT (2008). Flavonols and an oxychromonol from Piliostigma reticulatum. Phytochem., ISSN 0031-9422 vol. 69 nº11., 2245-2250.

10. Bekro, Y., Bekro, J., Boua, BB., Tra Bi, F., Ehile EE (2007). Etude ethnobotanique et screening phytochimique de Caesalpinia benthamiana (Baill.) Herend et Zarrucchi (Caesalpiniaceae). Sci. Nat., Vol.4 n² 2: 217-225.

11. Brunton, LL (1996). Agents for control of gastric acidity and treatment of peptic ulcers. In Goodman and Gilman's the pharmacological Basis of Therapeutics, $9^{\text {th }}$ edn, McGraw-Hill: New York, 901-915.

12. Capasso, F., Pinto, A., Mascolo, N., Autore, G., Franco, MP (1988). Effects of flavonoids on PGE 2 and LDT4-induced contractions on the guinea pig isolated ileum. Pharmacol Res Commun, 20: 201-202.

13. Capasso, F., Mascolo, N., Izzo, AA., Gaginella, TS (1994). Dissociation of castor oil induced diarrhoea and intestinal mucosal injury in rat: effect of NG-nitro-L-arginine methyl ester. Br J Pharmacol, 113: 1127-1130.

14. Couper, IM (1987). Opioid action on the intestine: the importance of the intestinal mucosa. Life Sci., 41: 917-925.

15. Di Carlo, G., Autore, G., Izzo, AA., Maibline, P., Mascolo, N., Viola, P., Diumo, MV., Capasso., F (2005). Inhibition of intestinal mobility and secretion by flavonoids in mice and rats: structure activity relationshps. J Pharmacol., 45: 1054-1059.

16. Farack, UM., Kantz, U., Loescke,K (1981). Loperamide reduces the intestinal secretion but not the mucosal cAMP accumulation induced by cholera toxin. Naunyn Schmiedebers Arch Pharmacol., 317: 178-179.

17. Faud, AS., Bravnwold, E., Isselpacher, K., Wilson, JD., Martin, JB., Kasper, DL., Hauser, SL., Longo, DL (1998). Harrisson's Principles of Internal Medicine. New York, McCraw Hill Company., 1: 236-242.

18. Field, M., Rao, MC., Chang, EB (1989). Intestinal electrolyte transport and diarrhoea disease. N Engl J Med., 321: 800-806.

19. Fontaine, O (1988). Bacterial diarrhoea and treatment. Lancet., 331: 1234-1235.

20. Gabriel, A., Agbor., T, Leopold., N,Gogang., Y, Jeanne (2004). The antidiarrhoeal activity of Alchornea cordifolia leaf extract. Phytother res., 18: 873-876.

21. Gaginelia, TS., Bass, P (1978). Laxatives: an update on mechanism of action Life Sci., 23: 1001-1010.

22. Galvez, A., Zarzuelo, M., Crespo, M., Lorente, M., Ocete, A., Jimenez, J (1993). Antidiarrhoeic activity of Euphorbia hirta extract and isolation of active flavonoid constituent. Planta Med., 59: 333-336.

23. Guerrant, RL., Van gilder, T., Steiner, TS., Theilman, MN., Slutsker, L., Tauxe, RV (2001). Practice guidelines for the management of infectious diarrhea. Clin Infec Dis., 32: 331-35.

24. Havagiray, CR., Ramesh, C., Sadhna, K (2004). Studies on anti-diarrheal activity of Calotropis gigantean R.BR. in experimental animals. J. Pharmacol. Pharm. Sci., 7 (1): 70-75.

25. Hichhorn, $N(1980)$. The treatment of acute diarrhoea in children: an histirical and physiological perpective. Am J Cin Nutr., 33: 637-663.

26. Hostettmann K, Marston A, Ndjoko K, Wolfender J (2000). The potential of African plants as a Source of Drug. Curr. Org. Chem., 4: 973-1010.

27. Karim, SMM., Adaikan, PG (1977). The effect of the loperamide on prostaglandin-induced diarrhea in rat and man. Prostaglandins., 13: 321-331.

28. Longe, RL., Dipiro, JT (1992). Diarrhoea and constipation. In pharmacotherapy: A physiologic Approach, $2^{\text {nd }}$ edn, Dipio JT, Talbert RL, Hayes PE. Elsevier: New York, 566-578.

29. Macauder, PJ (1986). Favonoids affect acetylcholine, prostaglandin E and antigen mediated muscle contraction. Prog Clin Biol Res., 213: 489-492.

30. Maikere-Faniyo, R., Van Puyvelde, L., Mutwewingabo, A., Habiyaremye, F (1989). Study of Rwandese medicinal plants used in the treatement of diarrhea. J Ethnopharmacol., 26: 101-109

31. Méite, S., N'guessan, JD., Bahi, C., Yapi, HF., Djaman, AJ., Geude Guina, F (2009). Antidiarrheal activity of the ethyl acetate extract of Morinda morindoides in rats. Tropical Journal of Pharmaceutical Research, 8 (3): 2001-2007.

32. Mitjans M, Garcia L, Marrero E, Vinardell MP (2008). Study of ligmed-A, an antidiarrheal drug based on liguin, on rat small intestine enzyme activity and morphometry. J Vet Pharmacol Ther., 24: 349-351.

33. Mohd, AK., Naeem, AK., Qbal, AQ. Ghufran, A., Shadab, Z (2004). Protective effect of Arque-Ajeeb on acute experimental diarrhea in rats. Bio Med Central., vol. 1472-68882: 4-8. 
34. Mora, A., Paya, M., Rios, JL., Alcaraz, MJ (1990). Structure activity relationships of polymethoxy flavones and others flavonoids as inhibitions of non-emzymic lipid peroxiation. Biochem Pharmacol., 36: 317-322.

35. Mueller, MS., Mechler, E (2005). Medicinal plants in tropical countries: traditional use, experience, facts. Georg Thierme Verlag: Stuttgart, Germany.

36. Mujumdar, A., Misar, A., Upadhye, A (2005). Antidiarrhoeal activity of ethanol extract of the bark of Dalbergia lanceolaria. J Ethnophamacol., 102: 213-216.

37. Murugesan, T., Ghosh , L., Mukherjee, K., Das, J., Pal, M., Saha, BP (2000). Evaluation of Antidiarrhoeal Profile of Jussiaea Suffruticosa Linn. Extracts in rats. Phytother. Res., 14: 381-383.

38. Niemegeers, CJE, Lenaerts, FM., Janssen, PAJ (1974). Loperamide (R 18553), a novel type of antidiarrheal agent. Part 1. In vivo oral pharmacology and acute toxicity. Comparison with morphine, codeine, diphenoxylate and difenoxine. Arzneimittel-Forschung, 24: 1633-1636

39. Nikiema, JB., Vanhaelen, FR., Vanhaelen, M., Fontaine, J., De_Graef, C., Heenen, M (2001). Efects of anti-inflammatory triterpenes isolated from Leptadenia hastate latex on keratinocyte proliferation. Phytother Res., 15: 2, 131-4.

40. Oi, H., Matsuura, D., Miyake, M (2002). Identification in traditional herbal medications and confirmation by synyhetesis of factors that inhibit cholera toxin-induced fluid accumulation. Proc Natl Acad Sci USA., 99: 3042-3046.

41. Ojewole, JAO., Awe, EOA., Agatha, N (2009). Antidiarrheal activity of Hypoxis hemerocallidea corm aqueous extract in rodets. Phytother Res., 23: 965-971.

42. Pazhani, GP., Subramanian, NN., Arunchalam, G., Hemalatha, S., Ravichandran, V (2001). Antidiarrheal potential of Elephantopus scaber Linn leaf extract. Ind drugs., 38 (5): 269-271.

43. Pierce, N., Carpenter, C., Elliot, H., Greenough, W (1971). Effects of prostaglandins, theophylline and cholera exotoxin upon transmucosal water and electrolyte movement in canine jejunum. Gastroenterol., 60: 22-32.

44. Rao, VSN., Santos, FA., Sobrieka, TT., Souza, MF., Melo, LL., Silveira, ER (1997). Investigation of the gastroprotective and antidiarrhoeal propertives of ternatin, a tetramethoxyflavone from egletes viscose. Planta Med., 63: 1496-1497.

45. Robert, A., Nezamis, JE., Lancaster, C., Hanchar, AJ., Klepper, MS (1976). Enteropooling assay, a test for diarrhea produced by prostaglandins. Prostaglandins., 11: 809-8028.

46. Salawu, S O.,Tijani, A.Y.,Obidike,I C., Chindo,B A (2007). Evaluation of anti-diarrhoeal properties of methanolic Root extract of Piliostigma reticulatum in rats. Journal of Phytomedicine and therapeutic 12, 44-50.

47. Salawu, OA., Tijani, AY., obidike, IC., Rafindadi, HA., Emeje, M (2009). Anti-ulcerogenic properties of methanolic root extract of Piliostigma reticulatum (DC) Hoechst (Syn. Bauhinia reticulate DC) Leguminosae in rats. Afr. J . Pharm. Pharmacol., 3 (5): 252-258.

48. Sanchez De Medina, F., Galvez, J., Gonzalez, M., Zarzuelo, A., Barreli, K.E (1997). Effects of quercetin an epithelial chloride secretion. Life Sci., 67: 2049-2055.

49. SAS (1999). SAS/ETS User's guide, vers.6, $4^{\text {th }}$ ed. SAS Inst. Cary, NC.

50. Snyder, JD., Merson, MH (1982). The magnitude of the global problem of acute diarrhoeal disease: A review of acute surveillance data. Bull World Heath Organ., 60: 604-613.

51. Su, YL., Leung, LK., Bi, YR., huang, Y., Chen, ZY (2000). Antioxidant activity of flavonoids isolated from Scutellaria rehderiana. J Am Chem Soc., 77: 807-812.

52. Suleiman, MM., Dzenda, T., Sani, CA (2008). Antidiarrheal activity of the methanol stem-bark extract of Annona senegalensis pers. J Ethnopharmacol., 116: 125-130.

53. Tripathi, K (1994). Essentials of Medical Pharmacology. Jaypee Brothers: New Delhi, 775.

54. Vimala, R., Nagarajan, S., Alam, M., Susan, T., Joy, S (1997). Anti-inflammatory and antipyretic activity of Michelia champaca Linn., (white variety), Ixora brachiata Roxb. And Rhynchosia cana (Willd.) D.C. flower extract, Indian J Exp Biol., 35: 12, 1310-4.

55. Yelemou, B., Bationo, B., Yameogo, G., Millogo-Rasolodimby, J (2007). Bois et Forêts des tropiques. ISSN 0006-579X, CODEN., N²91: 55-66.

56. Zhou, S., Gao, Y., Jiang, W., Huang, M., Xu, A., Paxton, JW ( 2000). Interactions of herbs with cytochrome P450. Drug Metab Rev., 35: 35-98. 